\title{
Intraocular pathology of trisomy 18 (Edwards's syndrome): report of a case and review of the literature
}

\author{
JOSEPH P. CALDERONE, JEREMY CHESS, GARY BORODIC, AND \\ DANIEL M. ALBERT
}

From the Howe Laboratory of Ophthalmology, Harvard Medical School, Massachusetts Eye and Ear Infirmary, Boston, USA

SUMMARY The ophthalmic histopathology is detailed in a case of trisomy 18 (Edwards's syndrome). In addition to the ocular pathology already reported, previously unreported findings of iris stromal hypoplasia, abnormal lens shape, and decreased ganglion cells in the retina are noted. The ophthalmic histopathology associated with this syndrome and the relationship of several genetic disorders to their ocular manifestations are discussed.

Trisomy 18 (Edwards's syndrome) is second only to trisomy 21 (Down's syndrome) as the most frequently occurring autosomal trisomy in neonates. ${ }^{12}$ Estimates of its frequency range from once in 3500 births $^{1}$ to once in 14000 births. $^{3}$ Since 1960 , when Edwards and his associates described the first cytogenetically documented case of trisomy $18,{ }^{4}$ over 130 abnormalities involving all organ systems have been related to this chromosomal aberration. ${ }^{\prime}$

Female infants are 3 times more likely to have this trisomy than are male. Affected infants are often born to women of advanced maternal age, and have a limited capacity for survival. ${ }^{\prime} 50 \%$ of these patients die within 2 months of birth, and only one in 10 survives the first year of life. ${ }^{\prime}$ The oldest patient reported with trisomy 18 was 15 years old. ${ }^{5}$ Common systemic findings (Table 1) are in particular the peculiar facies (Fig. 1), the shape of the cranium, and skeletal and cardiac anomalies. Central nervous system pathology, including the visual portions of the brain (Table 2), have also been reported but in less than $10 \%$ of the cases. ${ }^{167}$

Initial reports emphasised the clinical ocular findings ${ }^{8}$ (Table 3). In 1968 Ginsberg et al. presented the first comprehensive study of the ocular histopathology in trisomy $18 .^{8}$ Subsequently, many additional ocular pathological findings have been described. ${ }^{9-20}$ We now report the pathology of 2 eyes from a patient with trisomy 18 with previously

Correspondence to Professor Daniel M. Albert MD. Massachusetts Eye and Ear Infirmary, 243 Charles Street, Boston, MA 02114. USA.
Table 1 Systemic findings of trisomy $18^{*}$

\section{General}

Altered gestational timing: $1 / 3$ premature, $1 / 3$ postmature Polyhydramnios

Feeble fetal activity, weak cry

Growth deficiency

Mental deficiency, delayed psychomotor development

Cardiac anomalies: ventricular septal defect, patent ductus arteriosus. arterial septal defect

Abdominal anomalies: Meckel's diverticulum. intestinal malrotation Renalanomalies: horseshoe kidney, double ureter, cystic parenchyma Hernias: inguinal, umbilical, diaphragmatic

Genital anomalies: cryptorchidism, prominent clitoris

Musculoskeletal

Hypoplasia of skeletal muscle and subcutaneous and adipose tissue Flexion contractures

Overlapping of index, fourth, and fifth fingers over third finger

Short or abnormal sternum

Small pelvis with limited hip abduction

Rockerbottom feet

Syndactyly

Prominent occiput, narrow bifrontal diameter

Low-set, incompletely rotated, malformed ears

Micrognathia

Small triangular mouth inadequate for breast feeding

${ }^{*}$ Modified from Smith.' Warkany et al. ${ }^{6}$ and Apple. ${ }^{23}$

unreported iris stromal hypoplasia, abnormality of lenticular shape, and decreased ganglion cells in the retina. We also review the literature on the ocular histopathology and aetiology of this syndrome.

\section{Case report}

A white girl, weight $1740 \mathrm{~g}$, was born to a healthy, 


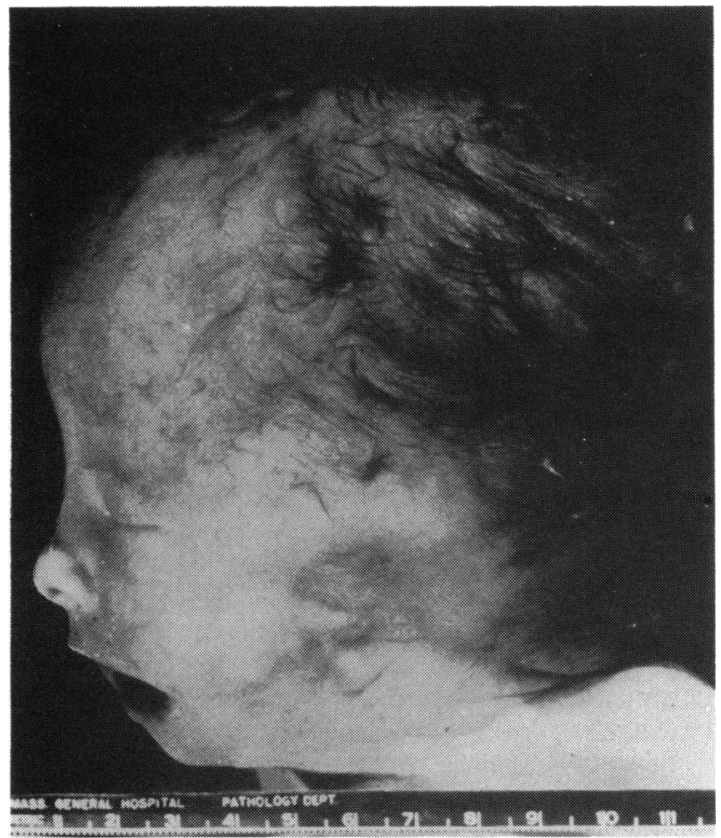

Fig. 1 Trisomy 18. Micrognathia and absent external ear.

26-year-old, gravida-2, para-1 mother at 36 weeks of gestation. The pregnancy was complicated during its final weeks by polyhydramnios and premature labour. The baby was delivered by caesarean section. Although there was a cousin with mental retardation, there was no other family history of birth defects and the older sibling was normal.

The baby had Apgar scores of 2 and 5, and required resuscitation. She was intubated, maintained on respiratory support, and given antibiotics.

Multiple congenital anomalies were noted, including narrow palpebral fissures, an apparently absent left ear, a dysplastic, low-set right ear, micrognathia, a large anterior fontanelle, tracheooesophageal fistula, a short sternum, syndactyly of the toes on both feet, a prominent clitoris, and an anteriorly placed anus.

On chest examination decreased air entry was noted bilaterally. Cardiac examination revealed sinus rhythm, right ventricular lift, but no significant murmurs. The abdomen was soft, protuberant, without organomegaly, and bowel sounds were present.

Chest $x$-ray revealed a ground-glass appearance with air bronchograms and diminished volume, 11 ribs, and increased air in the bowel. Cranial ultrasound showed hydrocephalus. Further $x$-ray studies confirmed the presence of tracheo-oesophageal fistula with a blind oesophageal pouch.

There was continued respiratory distress. Tracheo-
Table 2 Central nervous system findings of trisomy $18^{*}$

\section{General}

Abnormal cerebellum

Abnormal gyri including asymmetry and microgyri

Lumbar (myelo-) meningocele

Hydrocephalus

Paucity of myelination

Facial nerve palsy

Central visual system

Absent corpus callosum

Absent geniculate body

Absent occipital lobes ${ }^{20}$

Occipital lobe haemorrhage ${ }^{21}$

${ }^{*}$ Modified from Smith.' Warkany et al.. ${ }^{6}$ and Passarge et al. ${ }^{7}$ except where otherwise noted.

oesophageal fistula necessitated decompression gastrostomy to relieve gastrointestinal distention. A large pneumoperitoneum required treatment by decompression tube. Clinical suspicions that the combination of anomalies were consistent with trisomy 18 were later verified by karyotype (Fig. 2). The child died as a result of respiratory failure on the second day.

\section{NECROPSY}

In addition to the clinical features mentioned above, the head was large in comparison with the facial features, the hair was woolly, and the uvula was bifid. The thyroid was partially cystic, the lower oesophagus

Table 3 Clinically evident ocular manifestation of trisomy 18

\section{Globe}

Corneal opacities, clouding 8-10 13-17 $19202341-45$

Microphthalmos' 911 is $1820234244-45$

Colobomata' $112023424448-50$

Cataractous changes' 8111418202351

Persistent hyaloid artery ${ }^{8} 112348$

Glaucoma 202343

Other: blue sclera, absent retinal pigment, nictitating membrane. ${ }^{89141820414451}$ pupillary membrane, conjunctiva overriding the cornea, short radius of corneal curvature Adnexa

Slanted or narrow palpebral fissures ${ }^{17-9} 1418234652-55$

Epicanthus' $182023414247515356-59$

Ptosis 181020234160

Abnormally thick lids ${ }^{823}$

Abnormally long or sparse lashes ${ }^{848}$

Inability to close lids ${ }^{1855}$

Blepharophimosis ${ }^{2023}$

Orbit

Shallow orbits, hypoplastic orbital ridges 781418202341425361

Hypertelorism, hypotelorism ${ }^{18-10} 1418234756$

Neuro-ophthalmology

Strabismus, lateral gaze, asynergy of extraocular movement ${ }^{810} 18204142546263$

Decreased response to visual stimulus 91013184353 Nystagmus 8918206465

Anisocoria 20486460 


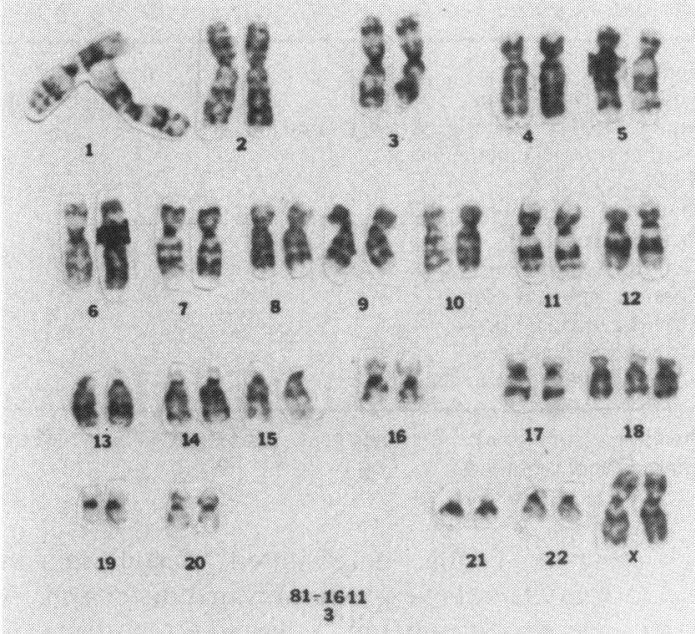

Fig. 2 Trisomy 18. Karyotype.

communicated with the trachea at the carina, and there was no xyphoid process.

The left lung was hypoplastic. The foramen ovale and ductus arteriosus were both patent. In addition the heart had right ventricular hypertrophy and dilatation, and there was a large, high ventricular septal defect. There was bilateral eventration of the diaphragm.

The right adrenal gland was hypoplastic, as was the right kidney. The left kidney was large and hydronephrotic, with a dilated ureter which drained

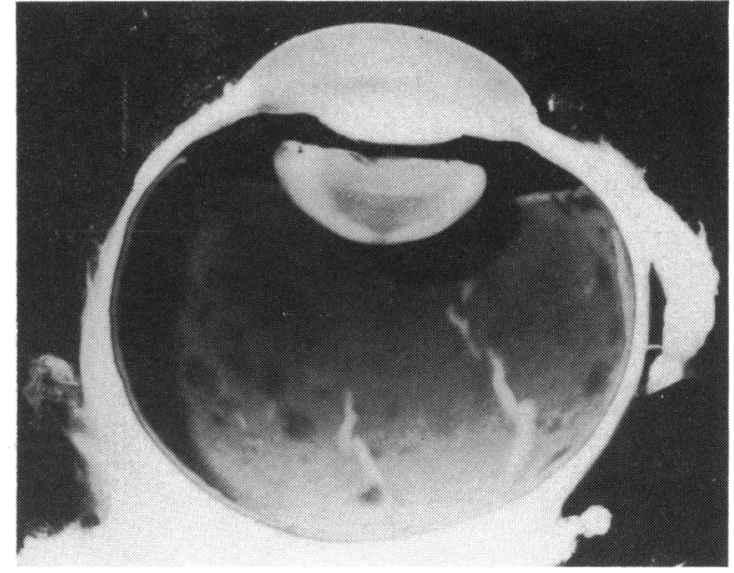

Fig. 3 Section of left eye with retinal haemorrhages and abnormal lens shape.

ectopically into the midline posterior wall of the bladder.

There was a large subarachnoid clot covering the entire right temporal region, with extension to the occipital lobe. Both occipital lobes were present.

\section{ocular pathology}

Gross examination. The globes measured $16 \times 15 \times 17$ $\mathrm{mm}$, the corneas $7 \times 8 \mathrm{~mm}$, and the pupils $3 \mathrm{~mm}$ in diameter. The eyes were sectioned in the horizontal plane. In the right eye the cornea was thickened and had a short radius of curvature. The anterior chamber was unremarkable and the angles appeared to be
Fig. 4 Atrophic iris and tunica vasculosa lentis remnant.

(Haematoxylin eosin, $\times 285)$.
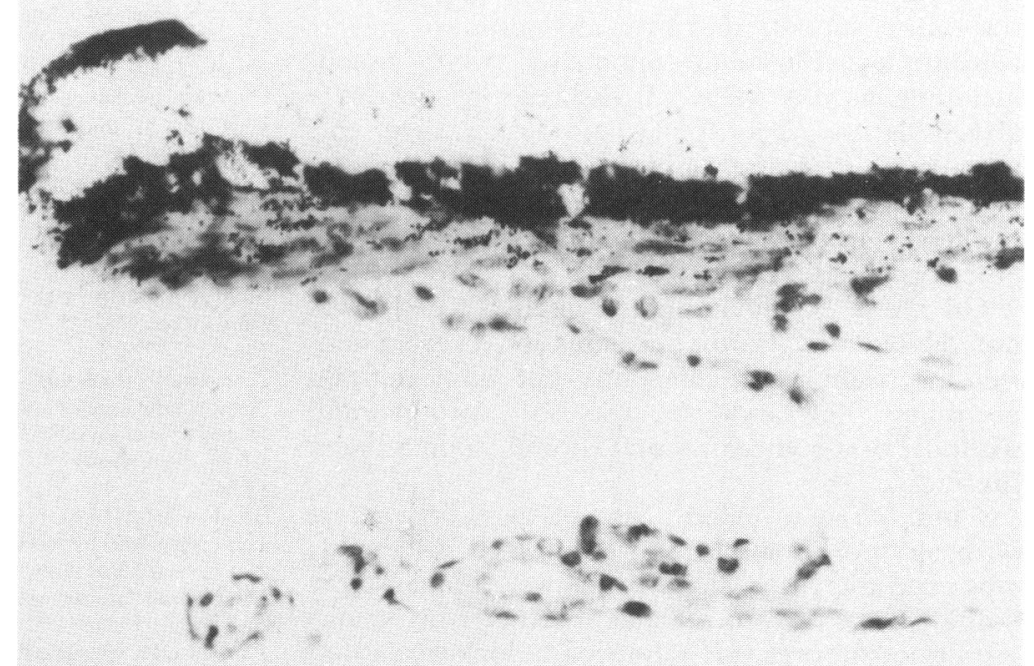


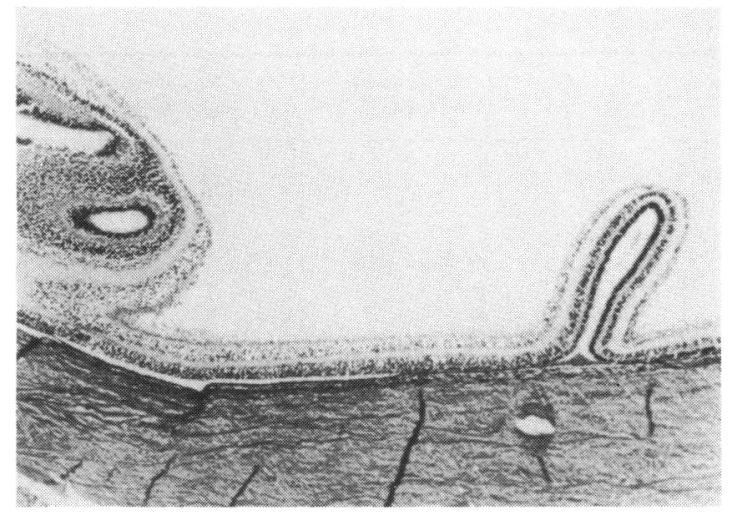

Fig. 5 Retinal fold and dysplastic retina. (Haematoxylin and eosin, $\times 20$ ).

open. The iris was blue but otherwise unremarkable. The lens was intact. The vitreous body was clear. The retina showed multiple, flat, preretinal haemorrhages, and central white areas (Fig. 3). The conjunctival tissue, ciliary body, choroid, optic disc, optic nerve, and sclera were all unremarkable. The gross findings of the left eye were similar.

Microscopic examination. In the right eye the corneal epithelium and Bowman's membrane were normal. The corneal stroma appeared thickened and

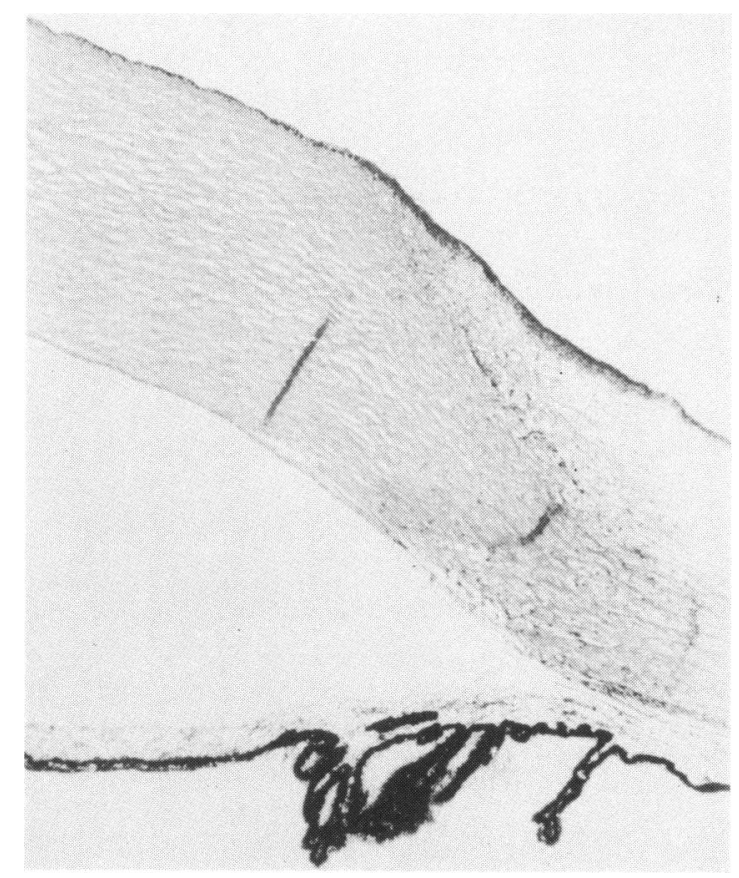

Fig. 6 Anterior chamber angle showing incomplete cleavage and hypoplastic ciliary processes. (Haematoxylin and eosin, $\times 115$ ). hypercellular. The endothelium and Descemet's membranes were normal. The conjunctiva was unremarkable. The angle was incompletely cleaved, and the trabecular meshwork and the scleral spur were poorly developed. The iris stroma was hypoplastic. A distinct sphincter or dilator pupillae could not be seen in the right eye, while both muscles were apparent in the left eye. Loosely adherent to the anterior surface of the iris was a remnant of the tunica vasculosa lentis, a membrane with blood vessels surrounded by poorly differentiated mesenchymal cells (Fig. 4). There was vacuolisation of the iris pigment epithelium. Hypoplastic ciliary processes were attached to the iris base. The ciliary muscle was not well developed. The anterior surface of the lens was concave and the posterior surface convex. There was posterior migration of the lens epithelium.

The choroid was highly cellular. The vitreous body was unremarkable. Multiple areas of haemorrhage within the retinal nerve fibre layer and outer nuclear layer were noted. In the left eye there were also subretinal haemorrhages. There were retinal folds, including Lange's fold, and areas of retinal dysplasia (Fig. 5). The nerve fibre layer was poorly developed. There was a diminished number of ganglion cells throughout. The retinal pigment epithelium displayed hypopigmentation between the region of the equator and the optic disc. The optic nerve was hypoplastic and gliotic. Staining with luxol fast blue demonstrated a reduction in myelin, and Bodian staining showed reduced axis cylinders. There was an optic nerve pit. The sclera was intact throughout.

The microscopic findings of the left eye were similar except that a remnant of the tunica vasculosa lentis was noted in the pupil.

\section{Discussion}

More than 350 articles representing several hundreds of case reports of trisomy 18 have appeared since its initial description by Edwards et al. ${ }^{4}$ However, to our knowledge, only 13 articles include some mention of ocular histopathology, ${ }^{8-20}$ and 5 deal with the subject in detail. ${ }^{812-1417}$ The limited abnormalities of the external eye apparent clinically and the resulting low incidence of post-mortem ocular examination may have contributed to the misconception that ocular defects are not a common phyenotypic manifestation of trisomy 18 .

Although ocular findings alone are not sufficient to arrive at a definitive diagnosis of the syndrome, a large number of ophthalmic anomalies have been described. We have reviewed the literature in an attempt to estimate the frequency of the documented ocular histopathological findings (Table 4). The relatively low number of cases per finding is not 
Table 4 Ocular histopathology of trisomy $18^{*}$

\begin{tabular}{|c|c|c|}
\hline Finding & $\begin{array}{l}\text { Present } \\
\text { case }\end{array}$ & $\begin{array}{l}\text { No. of cases finding } \\
\text { specifically noted }\end{array}$ \\
\hline \multicolumn{3}{|l|}{ Cornea and conjunctiva } \\
\hline $\begin{array}{l}\text { Decemet's membrane anomalies }{ }^{8} 1319 \\
\text { (absence, 'poor definition,' hypoplasia, irregular thickening) }\end{array}$ & - & 6 \\
\hline $\begin{array}{l}\text { Bowman's membrane anomalies } \\
\text { (absence, partial absence, hypertrophy, irregular thickening) }\end{array}$ & - & 5 \\
\hline $\begin{array}{l}\text { Corneal stromal anomalies } \\
\text { (hyalinisation, lamellar irregularity, thickening, fibrosis, merging with anterior chamber mesoderm) }\end{array}$ & + & 5 \\
\hline $\begin{array}{l}\text { Endothelial anomalies }{ }^{8} 13141023 \\
\text { (redundancy, hyperplasia, multilayering, irregularity) }\end{array}$ & - & 4 \\
\hline Large, vacuolated basal epithelial layer of cornea ${ }^{8} 1418$ & - & 4 \\
\hline Corneal vascularisation ${ }^{9} 1323$ & - & 2 \\
\hline $\begin{array}{l}\text { Corneal epithelial thickness anomalies }{ }^{13} 18 \\
\text { (compression, central thinning) }\end{array}$ & - & 2 \\
\hline Keratinised corneal epithelium ${ }^{13} 14$ & - & 2 \\
\hline $\begin{array}{l}\text { Conjunctival anomalies }{ }^{14} \\
\text { (stromal thickening, goblet cell hyperplasia, epithelial nests, lymphatic dilatation) } \\
\text { Angle Structures and anterior chamber }\end{array}$ & - & 2 \\
\hline Anomalies of Schlemm's canal, trabecular meshwork, scleral spur ${ }^{81319}$ & + & 5 \\
\hline Incomplete cleavage of anterior chamber angle ${ }^{13}$ & + & 2 \\
\hline $\begin{array}{l}\text { Peripheral anterior synechiae }{ }^{15} \\
\text { Lens }\end{array}$ & - & 1 \\
\hline $\begin{array}{l}\text { Cataractous changes } 13141923 \\
\text { (posterior subcapsular, anterior subcapsular, 'microscopic') } \\
\text { Uveal tract }\end{array}$ & + & 10 \\
\hline $\begin{array}{l}\text { Ciliary process anomalies } 8101314171923 \\
\text { (hyperplasia, hypoplasia, partial fusion, variable length) }\end{array}$ & + & 10 \\
\hline $\begin{array}{l}\text { Iris pigment epithelium anomalies }{ }^{81219} 19 \\
\text { (hyperplasia, irregularities, vacuolisation) }\end{array}$ & + & 6 \\
\hline $\begin{array}{l}\text { Iris stromal anomalies }{ }^{81314} \text { (blunt pupillary border, dilated vessels, pigment irregularities, hyperplasia, merging with anterior } \\
\text { chamber mesoderm) }\end{array}$ & + & 6 \\
\hline $\begin{array}{l}\text { Choroidal anomalies } \\
\text { (vascular congestion, compression, hypopigmentation, hypercellularity) }\end{array}$ & + & 5 \\
\hline $\begin{array}{l}\text { Iris sphincter anomalies } 814 \\
\text { (interruptions, hypertrophy, absence) }\end{array}$ & + & 4 \\
\hline Origin of ciliary process from iris base $\mathrm{s}^{81114}$ & + & 3 \\
\hline Tunica vasculosa lentis remnants 18 i9 & + & 3 \\
\hline $\begin{array}{l}\text { Hypoplastic ciliary muscle }{ }^{13} \\
\text { Retinal pigment epithelium }\end{array}$ & + & 2 \\
\hline $\begin{array}{l}\text { Retinal pigment epithelium } \\
\text { Hypopigmentation in region of posterior pole } 1819\end{array}$ & + & 5 \\
\hline $\begin{array}{l}\text { Redundancy or proliferation } 81417 \\
\text { Retina and vitreous }\end{array}$ & - & 4 \\
\hline Folds $8^{8} 1214-17$ & + & 10 \\
\hline Dysplasia $^{17} 19$ & + & 5 \\
\hline Hyperplasia or hypertrophy of different layers ${ }^{814}$ & - & 4 \\
\hline Persistent hyaloid artery 111423 & - & 3 \\
\hline Haemorrhage ${ }^{1314}$ & + & 2 \\
\hline Gliosisi4 $^{14}$ & + & 2 \\
\hline $\begin{array}{l}\text { Internal limiting membrane anomalies }{ }^{8 / 4} \\
\text { (thickening. detachment) }\end{array}$ & - & 2 \\
\hline Coloboma is & - & 1 \\
\hline $\begin{array}{l}\text { Endothelial proliferation of central artery and vein }{ }^{14} \\
\text { Optic nerve }\end{array}$ & - & 1 \\
\hline Coloboma $^{12171920}$ & _- & 5 \\
\hline Disc excavation 81317 & + & 4 \\
\hline Hypoplasia ${ }^{19} 20$ & + & 4 \\
\hline Gliosis $^{814}$ & + & 3 \\
\hline Sclera & & \\
\hline Thickening "1 14 & - & 2 \\
\hline $\begin{array}{l}\text { Ectasia adjacent to optic nerve coloboma }{ }^{12}{ }^{17} \\
\text { Extraocular muscle }\end{array}$ & - & 2 \\
\hline $\begin{array}{l}\text { Extraocular muscle } \\
\text { Anomalous medial rectus insertion" }\end{array}$ & - & 1 \\
\hline Unusually well developed medial rectus ${ }^{14}$ & - & 1 \\
\hline
\end{tabular}

*Including 22 cases, the present case, and 10 additional globes. 
necessarily an indication of the low frequency of most findings but may reflect incomplete reporting.

The most commonly reported affected ocular structures appear to be the cornea, anterior uveal tract, lens, and retina. Anomalies of all of the corneal layers have been described, and stromal thickening was noted in the present case. Immaturity of the angle structures and anomalies of the ciliary processes, noted in this case (Fig. 6), are commonly reported. Iris anomalies are also frequently described, but stromal hypoplasia, as was found in the present case, has not been previously noted (Fig. 4). Likewise, the absence of the dilator pupillae, another finding in this case, has not been reported, although sphincter pupillae anomalies have been described. Cataractous changes have been reported. In this patient posterior migration of the lens epithelium was noted in conjunction with an anomalous shape, the lens being concave anteriorly (Fig. 3).

Retinal folds were the single most common histopathological finding in the cases reviewed (Fig. 5). Other common retinal observations include hypopigmentation of the posterior pigment epithelium, dysplasia, and areas of haemorrhage and gliosis. Each of these retinal anomalies was noted in our patient's eyes. Although there have been reports of hyperplasia or hypertrophy of the different retinal layers, this case is the first in which a poorly developed nerve fibre layer and a diminished number of ganglion cells are described. The multiple retinal haemorrhages observed in this case may not be specific findings in trisomy 18 but may be secondary to resuscitation and intubation at birth. Our findings of optic nerve pit, gliosis, and hypoplasia have been previously reported.

Since one-third of trisomy 18 babies are born prematurely (Table 1), it is important to distinguish the pathological changes of this syndrome from those of prematurity alone. For example, at birth the corneal stroma and choroid show increased cellularity. ${ }^{21}$ During the ninth month in the normal fetus anterior chamber mesoderm has disappeared only up to the trabecular meshwork, and certain ciliary muscle fibres are still developing. The hyaloid system does not fully disappear until the middle of the eighth month of gestation. ${ }^{22}$ Exact determination of fetal age as well as a variability in ocular development may lead to difficulties in interpretation of several of the reported findings. However, the presence of colobomata or retinal dysplasia, for example, is indisputably pathological, whereas incomplete angle cleavage or corneal stromal hypercellularity may represent developmental findings alone.

It is of interest to compare the intraocular manifestations of trisomy 18 with those of trisomy 13 (Patau's syndrome), which is well known for its intraocular findings, ${ }^{23-25}$ and Meckel's syndrome, which shares many ophthalmic findings with trisomy 13 but has a normal chromosome karyotype. ${ }^{26}$ All 3 syndromes are associated with microphthalmia, retinal dysplasia, cataracts, poorly differentiated angle structures, and optic nerve hypoplasia. In addition colobomata occur in both trisomies. Microphthalmia, retinal dysplasia, and most anomalies affecting these syndromes occur with increased incidence and severity in trisomy 13 . Colobomata, also less severe in trisomy 18 , tend to affect the posterior globe in the region of the embryonic cleft in this trisomy and the anterior aspect of the globe in trisomy 13. Persistant hyperplastic primary vitreous, intraocular cartilage, and cyclopia are found, for the most part, only in trisomy 13 . The anomalies which appeared in our case were of the level of severity expected in trisomy 18.

The presence of ocular defects associated with aberration of chromosomes 13 and 18 as well as the similar nature of the ocular histopathology in the syndromes of ring chromosome 18 and trisomy 13 have been used to suggest a connection between genes important in ocular development on these chromosomes. ${ }^{23} 27$ For example, recent work associating retinoblastoma with the deletion of a specific section of the long arm of chromosome 13 in conjunction with other eye abnormalities, including microphthalmia and iris coloboma, ${ }^{28}$ lends additional support to the existence of such genes.

Ginsberg et al. postulate that the basic effect of the extra chromosome 18 may be related to the initiation of widespread, abnormal cellular proliferation and hyperplasia. ${ }^{14}$ Nodules of embryonic renal tissue in the kidneys of 5 trisomy 18 patients exemplify this abnormality. ${ }^{29}$ Others have noted heterotopia in various locations within the central nervous system. ${ }^{930}$ As already noted, hyperplastic ocular changes occur in trisomy $18 . .^{814}$

A theory put forth by Levkoff $e t$ al. $^{31}$ and supported by Hall ${ }^{32}$ considers the 3 autosomal trisomies 13,18 , and 21 . They suggest that the extra autosome may be the source of widespread developmental defects. Specifically, the additional DNA content caused by the third chromosome is not accompanied by an increase in the amount of RNA precursors. Instead, the amount of messenger RNA produced is apportioned differently, with a greater change associated with a larger chromatin excess. In other words the larger the extra autosome, the more deviant the phenotypic response. This hypothesis has support when the ocular or systemic effects of trisomes 13, 18, and 21 are compared. The most pronounced changes are found in individuals with trisomy 13 and the least in trisomy 21 . Correspondingly, chromosome 13 is the largest of the 3 chromosomes and chromosome 21 is the smallest. 
Hoehn supports this theory, noting, however, that the proportion of genetically relevant information within an extra or missing chromosome is an additional parameter involved in the phenotypic alterations of chromosomal imbalance. ${ }^{33}$ Kurnit agrees with this position, ${ }^{34}$ citing the work of Skinner $^{35}$ and Brown ${ }^{26}$ as examples showing that variation of nontranscribed, highly repeated DNA segments comprising constitutive chromosomal material is tolerated without clinical deficit.

The idea of amplified developmental instability, ${ }^{37} 38$ is based on the postulate that development is 'canalised,' i.e., it ordinarily proceeds along evolved pathways. ${ }^{39}$ The stability of these developmental tracks varies according to the degree of canalisation. Amplified developmental instability occurs as an effect of trisomy in that the extra chromosome alters this evolved developmental homoeostasis, resulting in diminished canalisation.

Another proposal ${ }^{40}$ concerns the type and countertype anomalies of trisomy 18 in which the ocular anomalies of the trisomy are compared with those of chromosome 18 deletion syndromes. Theoretically, whatever abnormality is 'caused' by the extra chromosome in the trisomy should be missing or replaced by its counterpart anomaly in the deletion syndromes.

Continued examination of the ocular histopathology seen in these chromosomal disorders may provide information on genetic factors in ophthalmic disease. Application of current advances in genetic technology may permit a more precise analysis of the relation of specific gene alterations to resulting ocular changes.

\section{References}

1 Smith DW. Recognizable patterns of human malformation. 2nd ed. Philadelphia: Saunders, 1976: 10-11.

2 Hamerton JL, Canning N. Ray M. Cytogenetic survey of 14609 newborn infants. I. Incidence of chromosome abnormalities. Clin Genet 1975; 8: 223-43.

3 Yanoff M. Fine BS. Ocular pathologv: a text and atlas. 2nd ed. Hagerston: Harper and Row, 1982: 42.

4 Edwards JH. Harnden DG. Cameron AH. Crosse VM. Wolff $\mathrm{OH}$. A new trisomic syndrome. Lancet 1960; i: 787-9.

5 Hook EB. Lehrke R. Rosner A. Yunis JJ. Trisomy 18 in a 15-year-old female. Lancet 1965; ii: 910-1.

6 Warkany J. Passarge E. Smith LB. Congenital malformations in autosomal trisomy syndromes. Am J Dis Child 1966: 112: 502-17.

7 Passarge E. True CW. Sueoka WT. Baumgartner NR. Keer KR. Malformations of the central nervous system in trisomy $18 . J$ Pediatr 1966; 69: 771-8.

8 Ginsberg J. Perrin EV. Sueoka WT. Ocular manifestations of trisomy 18. Am J Ophthalmol 1968; 66: 59-67.

9 Huggert A. The trisomy 18 syndrome: a report of cases in the same family. Acta Ophthalmol (Kbh) 1966; 44: 186-95.

10 Cernea P. Pencea V. Scripcary G. Harmanschi A. Lésions oculaires dans la trisome 17. Arch Ophtalmol (Paris) 1966; 26: $345-54$.

11 Keith CG. The ocular findings in the trisomy syndromes. Proc $R$ Soc Med 1968: 61: 251-3.
12 Davis P. De Gandt D. Dedion J. La trisomie 18. Bull Soc Belge Ophtalmol 1969; 152: 497-506.

13 Kolbert GS, Sellenfreund M. Sclerocornea, anterior cleavage syndrome, and trisomy 18. Ann Ophthalmol 1970; 2: 26-30.

14 Ginsberg J, Bove K. Nelson R. Englander GS. Ocular pathology of trisomy 18. Ann Ophthalmol 1971; 3: 273-9.

15 Lautridou A. Le Marec B. Urvoy M. Lessard M. Senecal J, Ardouin M. A propos de l'examen histopathologique oculaire de quatre cas de trisomie 18. In: Fourth International Congress of Human Genetics. Amsterdam: Excerpta Medica, 1971: 108-109.

16 François J, Berger R. Saraux H. Les aberrations chromosomiques en ophtalmologie. Paris: Masson. 1972: 275.

17 Mullaney J. Ocular pathology in trisomy 18 (Edwards's syndrome). Am J Ophthalmol 1973; 76: 246-54.

18 Rodrigues MM, Punnett HH, Valdes-Dapena M. Martyn LJ. Retinal pigment epithelium in a case of trisomy 18 . Am J Ophthalmol 1973; 76: 265-8.

19 Fulton AB, Craft JL, Zakov ZN, Howard RO, Albert DM. Retinal anomalies in trisomy 18. Albrecht von Graefes Arch Klin Ophthalmol 1980; 213: 195-205.

20 Howard RO. Classification of chromosomal eye syndromes. Int Ophthalmol 1981; 4: 77-91.

21 Mann I. The development of the human eve. New York: Grune and Stratton. 1950: 16-45.

22 Duke-Elder S. System of ophthalmology. Normal and abnormal development. St Louis: Mosby, 1963: 3(1): 291-312.

23 Apple DJ. In: Goldberg MF, ed. Genetic and metatolic eve disease. Boston: Little. Brown. 1974: 532-49.

24 Patau K. Smith DW. Therman E. Inhorn SL. Wagner HP. Multiple congenital anomalies caused by an extra chromosome. Lancet 1960; i: 790-2.

25 Ginsberg J. Perrin EV. Ocular manifestations of 13-15 trisomy. Arch Ophthalmol 1965; 74: 487-94.

26 MacRae DW. Howard RO. Albert DM. Hsia YE. Ocular manifestations of the Meckel syndrome. Arch Ophthalmol 1972; 88: $106-13$.

27 Jay M. The eve in chromosome duplications and deficiencies. New York: Dekker. 1977: 120-1

28 Howard RO. Warburton D. Breg WR. Miller OJ, McKeown J, Rubin SP. Retinoblastoma and partial deletion of the long arm of chromosome 13. Trans Am Ophthalmol Soc 1978; 76: 172-83.

29 Bove KE. Koffler H, McAdams AJ. Nodular renal blastema: definition and possible significance. Cancer 1969; 24: 323-32.

30 Terplan KL. Lopez EC. Robinson HB. Histologic structural anomalies in the brain in the trisomy 18 syndrome. Am J Dis Child 1970; 119: 228-35.

31 Levkoff AH. Matter GB. Eisenstein RP. A case of trisomy 16-18 syndrome. Am J Dis Child 1964; 107: 300-3.

32 Hall B. Delayed ontogenesis in human trisomy syndrome. Hereditas 1965; 52: 334-43.

33 Hoehn H. Annotation: functional implications of differential chromosome banding. Am J Hum Genet 1975; 27: 676-86.

34 Kurnit D. Down's syndrome: gene dosage at the transcriptional level in skin fibroblasts. Proc Natl Acad Sci USA 1979; 76: 2372-5.

35 Skinner DM. Satellite DNA's. Bioscience 1977; 27: 790-6.

36 Brown SW. Heterochromatin. Science 1966; 151: 417-25.

37 Shapiro BL. Prenatal dental anomalies in mongolism: comments on the basis and implications of variability. Ann NY Acad Sci 1970; 171: 562-77.

38 Shapiro BL. Amplified developmental instability in Down's syndrome. Ann Hum Genet 1975; 38: 429-37.

39 Waddington $\mathrm{CH}$. The canalization of development and the inheritance of acquired characters. Nature 1942; 150: 563-5.

40 Saraux H. Types et contres-types en pathologie chromosomique. Bull Soc Ophtalmol Fr 1972; 85: 8-16.

41 Smith DW. Patau K. Therman E. Inhorn SL. The no. 18 trisomy syndrome. J Pediatr 1962; 60: 513-27. 
42 Butler LJ, Snodgrass GJ. France NE. Sinclair L. Russell A. E(16-18) trisomy syndrome: analysis of 13 cases. Arch Dis Child 1965: 40: 600-11.

43 Townes PL. Manning JA. DeHart GK. Trisomy 18 associated with congenital glaucoma and optic atrophy. J Pediatr 1962; 61: 755-8.

44 Townes PL. Kreutner KA. Kreutner A. Manning J. Observations on the pathology of the trisomy 17-18 syndromes. J Pediatr 1963; 62: 703-11.

45 Nakagome Y, Komiya K. Arima M. A case of trisomy 18 syndrome. Paediatria Universitatis Tokyo 1963; 8: 48-53.

46 Garcia-Castro JM, de Torres LCR. Nictating membrane in trisomy 18 syndrome. Am J Ophthalmol 1975; 80: 550-1.

47 Taylor AI. Autosomal trisomy syndromes: a detailed study of 27 cases of Edwards's syndrome and 27 cases of Patau's syndrome. $J$ Med Genet 1968; 5: 227-41.

48 Weber WW. Mamunes P. Day R. Miller P. Trisomy 17-18 (E): studies in long-term survival with report of two autopsied cases. Pediatrics 1964: 34: 533-41.

49 Hecht F. Bryant JS. Motulsky AG. Giblett ER. The no. 17-18 (E) trisomy syndrome. J Pediatr 1963; 63: 605-21.

50 Heimann K. Jaeger W. Dollman A. AugermiBbildungen bei einem Kind mit überzähligem chromosomenfragment. Opthalmologica 1968; 155: 390-5.

51 Smith DW. Patau K. Therman E. Inhorn SL. A new autosomal trisomy syndrome: multiple congenital anomalies caused by an extra chromosome. J Pediatr 1960; 57: 338-45.

52 German JL III. Rankin JK. Harrison PA. Donovan DJ, Hogan WJ. Bearn AG. Autosomal trisomy of a group 16-18 chromosome. J Pediatr 1962; 60: 503-12.

53 Gottlieb MJ. Hirschorn K. Cooper HL. Lusskin N. Moloshok RE. Hodes HL. Trisomy 17 syndrome: report of three cases and review of the literature. Am J Med 1962; 33: 763-73.
54 Holman GH, Erkman B. Zacharies DL, Koch HF. The 18 trisomy syndrome - two new clinical variants. N EnglJ Med 1963; 268: $982-8$

55 Jue KL. Lockman LA, Edwards JE. Anomalous origins of pulmonary arteries from pulmonary trunk ('crossed pulmonary arteries'): observation in a case with 18 trisomy syndrome. Am Heart J 1966; 71: 807-12

56 Finley WH. Finley SC. Carle ET. 17-18 trisomy syndrome: review and report of a case. Am J Dis Child 1963; 106: 591-6.

57 Lewis AJ. The pathology of 18 trisomy. J Pediatr 1964; 65: 92-101.

58 Voorhees ML, Aspillasa MJ, Gardner LI. Trisomy 18 syndrome with absent radius, varus deformity of hand, and rudimentary thumb: report of a case. J Pediatr 1964; 65: 130-3.

59 Windmiller J. Marks JF, Reimold EW, Costales F, Peake C. Trisomy 18 with biliary adhesion: report of a case. J Pediatr 1965 : 67: 327-8.

60) Voorhees ML. Vaharu T, Gardner LI. Trisomy 16-18 syndrome. Lancet 1962; ii: 992.

61 Crawfurd M d'A. Multiple congenital anomaly associated with an extra autosome. Lancet 1961; ii: 22-4.

62 Rohle RA. Hodgman JE, Cleland RS. Multiple congenital anomalies in the E-trisomy (group 16-18) syndrome. Pediatrics 1964; 33: $258-70$.

63 Matsuda $H$. Tamaka $H$. A case of 16-18 trisomy syndrome. Tokushima J Exp Med 1964; 10: 231-8.

64 Ozonoff MB. Steinbach HL. Mamunes P. The trisomy 18 syndrome. AJR 1964; 91: 618-28.

65 Steinberg JB, Jackson JF. The 16-18 trisomy syndrome. Am J Dis Child 1963; 105: 213-5.

66 Townes PL. DeHart GK Jr. Ziegler NA. Trisomy 17-18-An evaluation of preconceptional parental irradiation as a possible etiologic factor. J Pediatr 1964; 65: 870-9. 